\title{
Tourism as an Aspect of City Branding in Functional Urban Areas
}

\author{
EWA GLIŃSKA \\ Faculty of Engineering Management \\ Bialystok University of Technology \\ 45A, Wiejska Street, 15-351 Bialystok \\ POLAND \\ ANNA MATWIEJCZYK \\ Faculty of Engineering Management \\ Bialystok University of Technology \\ 45A, Wiejska Street, 15-351 Bialystok \\ POLAND \\ YAUHENIYA BARKUN \\ Faculty of Engineering Management \\ Bialystok University of Technology \\ 45A, Wiejska Street, 15-351 Bialystok \\ POLAND
}

\begin{abstract}
Functional Urban Areas (FUAs) are among the main actors of local development planning in the current perspective of the European Union. One of significant challenges in the management of such areas is the creation of an image or building of a city brand covering several neighboring municipalities. Among other things, tourist attractions can be used as important factors in defining metropolitan identity. The aim of the paper is to identify categories of tourist attractions that are used in the process of communicating FUAs' brands. The paper is focused on branding activities related to the tourism of selected FUAs in Poland. The research method involved a content analysis of documents entitled Strategies of Integrated Territorial Investments (ITI) developed for Polish FUAs. Research results show that branding activities of FUAs aimed at developing their tourism function are more material- than immaterial-oriented and concern only those issues that are dependent on local government authorities and not tourism companies. The paper contributes to the development of the city branding theory focusing on the issue of developing a tourist brand for FUAs. The key limitations of the paper are as follows: it is based on the analysis just one type of documents - ITI Strategies of Polish FUAs - and the specificity of content analysis as a research method.
\end{abstract}

Key-Words: - city marketing, city branding, Functional Urban Area, FUA, city tourism, tourist attraction Received: August 8, 2020. Revised: December 28, 2020. Accepted: January 9, 2021. Published: January 16, 2021

\section{Introduction}

Currently there exists high competition for tourists, requiring territorial units to implement the development strategies with a strong emphasis on the marketing component [1]. Place marketing is defined as "the coordinated use of marketing tools supported by a shared customer-oriented philosophy, for creating, communicating, delivering, and exchanging urban offerings that have value for the city's customers and the city's community at large" [2]. Cities are challenged by the creation of competitive brands. City branding goes beyond traditional promotion; it focuses on creating a strong brand image capable of binding together all functional and symbolic meanings towards a more effective approach [3,4]. City brand (as well as FUA brand) consists of elements, some of which cannot be changed (location), and other ones can be modified by appropriate measures (development of a modern infrastructure) [5]. Cities and their functional areas carry out branding activities to position themselves in the minds of tourists [6,7 cited in: 8,9].

Another challenge relates to the specifics of development of modern cities, vague borders between a city and its nearest communities. FUAs have gained special recognition in Poland in recent years. This is especially due to noticeable activities within the Integrated Territorial Investments (ITI) 
which are being prepared within these areas [10]. The term "Urban Functional Area" was first used in 2004 by the European Spatial Planning Observation Network [11]. A FUA can be considered a settlement system which is spatially continuous but consists of separate administrative units [12]. Though there is a number of differences between cities and FUAs, it is crucial for both of them to create strong brands.

The dynamic changes in views from post-socialist beliefs to the adoption of the idea of a free market have made Poland one of the most dynamically developing countries in terms of FUAs [13]. According to the recent data available on stat.gov.pl, there are currently 58 FUAs in Poland [14].

Metropolization as well as multi-directional and multi-level cooperation with the surrounding areas in the conditions of increasing territorial competition seem to be the only solution for large urban centers. As a result, FUAs appear as a structure that will govern the future functioning of cities [15].

The aim of the paper is the identification of categories of tourist attractions and facilities that are recognized and communicated as essential by FUAs' brands. This objective was achieved through the use of the empirical content analysis of ITI strategies developed for selected FUAs in Poland. The study was of a qualitative nature.

The current manuscript is designed as follows: the first chapter covers the principal theoretical aspects of city branding, the essence of FUAs and tourism in the context of cities and FUAs; in the second chapter the adapted methodology is explained; in the fourth chapter the strategical plans of FUAs are analyzed with a focus on their tourism component; the chapters five and six offer discussion and conclusions.

\section{Tourism in City Branding form the Perspective of Functional Urban Areas} 2.1 The Essence of the Functional Urban Areas

The city and its surroundings have been the source of many scientific works for several decades. As they become more connected, their boundaries getting blurred, FUAs emerge. The terms used previously to describe FUAs include commercial city, economic areas, urban complex or urban impact zone [16, p. 237]. According to the OECD, "FUAs consist of urban cores with a population density greater than 1,500 inhabitants per square kilometer and with at least $15 \%$ of the population working in the urban core"[17]. Intensification of commuting, characteristic of accelerated industrialization and unmet demand for work within the city limits has largely influenced the creation of FUAs [18]. Such cooperation, as is in FUAs' case, however, does not exclude natural competition between the entities that make up a given functional area. Currently about 3.69 billion people in the world belong to some FUAs, which represents $53 \%$ of the total population [19].

When delimiting the boundaries of a FUA, as can be seen in the example of Poland, voivodeship capitals were most often used as the core of these areas [20]. According to the National Spatial Development Concept 2030, four basic types of FUAs were distinguished based on their cores and surrounding zones: 1) voivodeship centers (consist of capitals of voivodeships); 2) regional centers (such FUAs are not created around voivodeship capitals, however, they play an important role on a national scale in the administrative, economic and social sphere); 3) subregional centers (focused on a regional measure that supports centers with a higher level of existence); 4) Local Centers [21, p. 179].

FUA development in Poland is diverse and conditioned by various regularities. Concentric spatial systems are most common here. It can be noticed that it is in the center where the strongest development processes take place, and their impact on the surrounding units results from the diffusion of distance-dependent development processes [22].

Polish FUAs develop documents called ITI strategies that are of great importance, which can be explained as follows: a) they support the sustainable development of both cores and neighboring units; $b$ ) they promote cooperation and strengthen the territorialization of the units that make up a given FUA; c) they facilitate and strengthen financial programming. In case of Poland, ITI strategies for voivodeship FUA centers are obligatory [10].

FUAs and cities themselves are becoming more important units at the level of global economy [23]. The proper planning of a FUA can and should be of real benefit to the areas in which it is located. This increases the competitiveness of the area at both national and international level [24]. FUAs, as important centers of social activity, follow the path of sustainable urban development [25].

\subsection{The Concept of City Branding}

The application of city marketing has become necessary as a result of technological progress and increased mobility of people and resources in the 21st century [26]. Cities, in order to stand out on the market, must create their distinctive image - strive to eliminate negative features and expose their unique resources, such as cultural heritage, architecture, local skills, etc. [27]. Place marketing has evolved over time and, according to Kavaratzis, the current stage of its development is place branding [28]. This 
means that marketing efforts of territorial units increasingly focus on evoking associations with a specific place of emotional, mental and psychological nature, as opposed to functional associations [29, p. 28].

Nowadays, city brands operate in various forms: national, regional, city branding. It is now not only a growing academic discipline, but also an increasingly common practice used by local governments [30, p. 13-14, 31, 28]. Branding is therefore becoming a common practice to 'sell' certain characteristics of a city, e.g. its history, lifestyle, culture in order to gain new opportunities, prestige or strength in a competitive environment [32].

The implementation of city-branding policies aims to support the city to react appropriately to current societal and economic challenges [26]. City branding is complex, it must account for many factors and associations of a given territory [33]. There are many benefits that a city with a strong and recognizable brand can offer, including increased inbound tourism rates $[34,35,36]$.

Territorial units aspiring to the tourist function may base their strategies for distinguishing themselves on such characteristics as: attractions, leisure opportunities on offer or high-quality services, as well as natural, cultural, social resources, infrastructure, accessibility and quality of transport, attitudes of inhabitants towards tourists, price levels, economic and social relations etc. [37].

The attributes of a city brand identity can be divided into two groups: material and immaterial [38, 39]. Material (or functional) elements are achieved through spatial development strategies (including the built environment, public space with urban design, green areas, architecture) [38]. Immaterial (or empirical, emotional) elements are achieved by combining symbolic and functional attributes of a city brand (e.g. the provision of entertainment and cultural services by the city) [38].

Different territorial units are deeply involved in the competition for tourists and are actively using branding tools [40, 41]. The role of cities as territorial units has been growing over the years, and now there is a shift from power concentration at the national level to regional, metropolitan and city levels [3].

Considering that FUAs merge the features of several territories, the approach for its branding becomes more sophisticated. Metropolitan areas carry out advanced activities in the field of creating a territorial brand. Due to the fact that larger cities have a longer history of connections with neighboring local governments, the level of advancement of their work on the branding concept is much more advanced [42].

\subsection{Urban Tourism versus City Branding Concept}

The development of tourism has a significant impact on cities and changes in urban space, hence this issue is more and more frequently addressed in research [43]. However, the most recent publications indicate that the subject of urban tourism persists at the margin of the debate on cities [44]. Urban tourism should be analyzed in the context of the functioning and management of cities as a whole. They both are inevitably studies of urban change, planning and management, and thus focus on the application of policies in the urban setting and tourism activity [45].

Urban tourism is a complex phenomenon to define, which has challenged many scholars. It is undoubtedly more complex than simply 'tourism performed in the cities' rather than in other sites, and it is not conceptually homogeneous to expressions such as 'sea tourism' or 'rural tourism' [46].

Among the characteristics of urban tourism Ashworth and Page indicate: a) a multi-purpose nature of city visits in a multifunctional context; $b$ ) visitors' use of urban facilities that are not necessarily built for visitors, c) the diversity of urban economy in which tourism takes place [47]. The co-presence of multiple economies in the urban context is fundamental for city tourism, so that cities with the largest and most varied economy will gain the highest benefits from tourism [44, 47].

Urban tourism covers a number of topics: heritage conservation, urban structure and infrastructure of tourism precincts, festivals and events, cultural, economic and social impacts etc. [48]. Currently researchers emphasize that a growing number of urban tourists are interested in entertainment, sports, shopping, gastronomy and other forms of urban life [43]. Hence, the " $5 \mathrm{~A}$ " model of tourist attractiveness of a city has appeared, which includes attractions, amenities, accommodation, access, and atmosphere [43, 49, pp 125-126].

Tourism makes a significant impact on the economy of a city; therefore, researchers investigate different approaches to city branding for tourism promotion [50, 51, 52]. Consequently, various urban areas implement policies and strategies to promote, market and brand places, and, therefore, improve the city for the sake of target groups such as visitors and tourists [4]. Those policies/strategies attempt to create and communicate the distinctiveness of the city [53]. The explicit focus of cities on tourist attraction make some researchers in the area of urban studies consider that "cities become commodities as a consequence of their repositioning towards tourism" [53]. Due to the variety of demands, 
interests and possibilities of different group of tourists, urban tourism can assume different forms.

From the perspective of city branding, the nature of tourism is complex and multidimensional. According to Beerli and Martin, factors influencing the assessments of the city image can be classified into nine dimensions: a) natural resources, b) general infrastructure, c) tourist infrastructure, d) tourist leisure and recreation culture, e) history and art, f) political and economic factors, g) natural environment, h) social environment and i) atmosphere of the city [54].

Within FUAs, tourism can bring significant benefits, such as new jobs, new investment opportunities or revenue generation that can be used to rebuild infrastructure and improve municipal facilities, to name just a few [55, p.71]. If the city center has the capacity to grow, it affects the surrounding municipalities. Therefore, improving the condition of the center is very important for the modernization and increasing the attractiveness of external areas as well [56, p. 41].

Due to the chosen topic of the article it is important to pay attention to tourism in the context of FUAs. The ability to manage this sector in a given area results mainly from regional programs, adopted development strategies, spatial development plans as well as established budgets and received subsidies. The development of the ITI strategy provides an opportunity to create one's own regional tourism policy, thanks to which a FUA can increase its level of innovation and competitiveness, while natural and cultural areas will retain their values through protective and revitalizing measures [23, 57].

\section{Research Methodology}

The research objective was answering the question: What categories of tourist attractions and facilities are recognized and communicated as essential by FUAs' brands? The method used to answer this question was the document analysis, namely systematic procedure for reviewing or evaluating documents - both printed and electronic. This method focuses on data examination and interpretation in order to obtain sense, understanding and development of empirical knowledge [58]. It can be used as a basic or a complementary method to the research process [58]. In this article, the latter approach is used, treating the results of document analysis as an introduction. As a result of the empirical material obtained during the analysis of documents, the authors of the article gained additional information to support the formulation of questions for in-depth interviews, the implementation of which is planned in the next phase of the research project.

The analysis may cover different categories of documents, including those in the possession of public institutions such as central or local government [58]. They are analyzed to determine the policies implemented by these organizations (e.g. $[59,60,61])$. This group of documents may also cover strategic studies created by entities coordinating the activities of local government units or their partnerships. These types of documents have become the subject of analysis in this article.

The subject of the analysis was the content of texts of strategic documents prepared by the offices of management boards of FUA associations in Poland. Polish FUAs were used as an example of FUA presentation due to their uniqueness in the rapid development and widespread emergence in this country $[12,13]$. According to the data available on the official website of the Statistical Office of Poland in 2018, there were 58 separate FUAs in Poland. Of these, 17 such areas were selected for the analysis.

The selection of FUAs as the subject of analysis results from three reasons: a) currently, Poland as a brand has a low position on the international market; b) the Polish Tourist Organization points out that voivodeship cities should be treated as brands; c) urban and cultural tourism should be treated as a priority in the process of building city brands [62].

In detail, the analysis involved 17 documents called "ITI Strategy for 2014-2020" prepared for the purpose of FUAs of voivodeship centers in Poland. It is a basic document defining development objectives and directions of activities of particular functional areas, and the legal basis for its preparation is at European level: Regulations (EU) No 1301/2013 of the European Parliament and of the Council of 17 December 2013, No 1303/2013 of 17 December 2013 and No 1304/2013 of 17 December 2013 [63, 64, 65]. At the national level, however: Article 74 of the Act of 8 March 1990 on Municipal Self-Government (i.e. Journal of Laws of 2015, item 1515), relevant agreements of individual FUAs concerning joint implementation of the ITI of Municipal Functional Areas and other legal bases applicable in the given areas [66]. These documents were available in pdf versions on the websites of the associations coordinating the activities of the various FUAs. The list of analyzed documents is represented below: 2020

1. ITI Strategy Białystok FUA for years 2014-

2. ITI Strategy for Bydgoszcz - Toruń FUA for 2014-2020

3. ITI Strategy for Gdańsk Gdynia Sopot Metropolitan Area till the year 2020 
4. ITI Strategy Gorzów Wielkopolski FUA for 2014-2020

5. ITI Strategy of Central Subregion of Śląsk Voivodeship for years 2014-2020

6. ITI Strategy Kielce FUA for years 2014-2020

7. ITI Strategy for Kraków FUA for 2014-2020

8. ITI Strategy Lublin FUA for years 2014-2020

9. Strategy of Development of Łódź Metropolitan Area $2020+$ 2020

10. Strategy of FUA of Olsztyn for years 2014-

11. ITI Strategy of Opole Agglomerations for years 2014-2020 2020

12. ITI Strategy of Poznań FUA for years 2014-

13. ITI Strategy Rzeszów FUA for years 20142020

14. ITI Strategy of Szczecin FUA for years 20142020

15. ITI Strategy for Warszawa FUA 2014-2020+ 2020

16. ITI Strategy Wrocław FUA for years 2014-

17. ITI Strategy Zielona Góra FUA or years 20142020

Each of the analyzed strategies had a similar structure, in which the diagnostic part and the strategic part can be identified. In each of the documents, the latter part was analyzed in detail, with an emphasis on analyzing records of objectives, priorities and actions of particular FUAs planned in the years 2014-2020.

Data on city branding goals and activities related to tourism planned in each of the FUAs were retrieved from the corresponding ITI documents. Each of the 17 documents contained information on tourism in the form of formulated objectives. Additionally, some FUAs with a more developed tourism sector (e.g. Gdańsk-Gdynia-Sopot) had separate subsections devoted to tourism-related activities.

The document analysis involved skimming (superficial examination), reading (thorough examination), and interpretation [58]. The research results were analyzed with consideration for the exploratory and interpretative character of the research material [67]. The analytic procedure consisted of finding, selecting, appraising (making sense of), and synthesizing data contained in documents. The document analysis provided data (excerpts and quotations) that were then organized into major themes, categories and case example [68]. The authors of the article, in carrying out research, tried to demonstrate objectivity (seeking to represent the research material fairly) and sensitivity (responding to even subtle cues to meaning) in the selection and analysis of data from documents [58].

The analysis of ITI strategies for particular FUAs consisted of the following steps: a) identification of development goals of FUAs related to their branding activity, b) identification of areas of performance of particular functional areas related to tourism, c) creation of categories of tourist attractions and facilities that are recognized and communicated as essential by FUAs' brands.

The aims of the article were achieved through directed content analysis in which, during the coding process, researchers make use of both codes formulated on the basis of the existing theory as well as the ones which they develop themselves, relying on obtained results [69, p. 1281].

\section{Research Findings}

As it was mentioned above, a growing number of cities create and develop their brands. City brands serve different purposes, and attracting tourists is among the dominant ones. The same can be stated for FUAs. All the examined FUAs recognize tourism as an essential aspect of development and included tourism-related goals into the plan.

Based on the findings of previous researchers, who recognized the importance of city branding for tourism promotion, the following 12 areas of interest were distinguished: natural resources (frequency: 11), infrastructure (10), heritage and urban regeneration (9), bicycle routes (7), unique features of the city (7), all-year-round attractiveness of a region (5), ICT applications and services related to culture and tourism (5), business tourism (2), festivals and other cultural activities (2), culinary aspects (1), international communication (1), rural areas (1) [50, 51, 52, 54].

Tab. 1: Material and immaterial areas of ITI Strategies

\begin{tabular}{|c|c|c|c|}
\hline Material-oriented & Freq. & Immaterial oriented & Freq. \\
\hline \multirow{9}{*}{$\begin{array}{l}\text { natural resources } \\
\text { infrastructure } \\
\text { heritage and urban } \\
\text { regeneration } \\
\text { bicycle routes } \\
\text { ICT applications } \\
\text { and services } \\
\text { related to culture } \\
\text { and tourism } \\
\text { international } \\
\text { communication } \\
\text { rural areas }\end{array}$} & 11 & unique features of & 7 \\
\hline & 10 & the city & \\
\hline & 9 & all-year round & 5 \\
\hline & 7 & region & \\
\hline & & business tourism & 2 \\
\hline & 5 & festivals and other & 2 \\
\hline & & $\begin{array}{l}\text { cultural activities } \\
\text { culinary aspects }\end{array}$ & \\
\hline & 1 & & \\
\hline & 1 & & \\
\hline Total & 44 & Total & 17 \\
\hline
\end{tabular}

*where Freq. - Frequency

Source: compiled by the authors. 
As the table 1 shows, all the identified objectives can be divided into material and immaterial oriented, and in most cases the FUAs are concentrated rather on material activities.

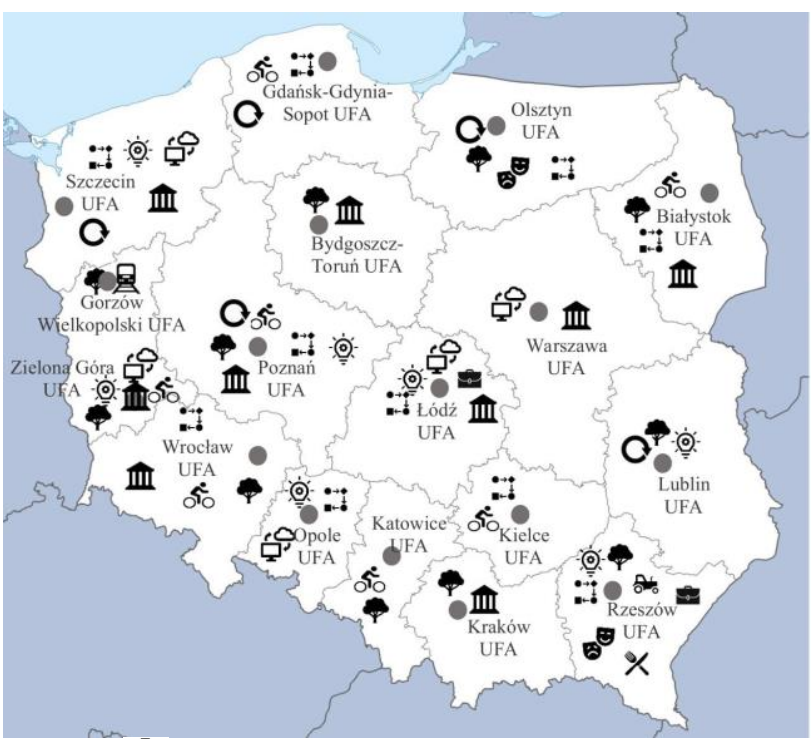

Where: $\mathbf{Q}$ - all-year-round attractiveness of a region, ণ culinary aspects, ${ }^{\otimes}$ - festivals and other cultural activities, 孟 - heritage and urban regeneration, 盢 international communication, and services related to culture and tourism, infrastructure, $\boldsymbol{\psi}$ - natural resources,

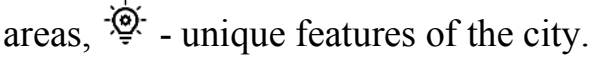

Fig. 1: Tourism-related branding goals from ITI strategies of FUAs

Source: compiled by the authors.

As the figure 1 shows, tourism-related goals are diverse and selected in accordance with regional specifics. In particular, the Rzeszów FUA intends to promote the region as an agri-tourism attractive environment, popularize regional gastronomy, invest in the business-tourism development. However, there are some common areas. The protection and use of the natural resources is the most frequently mentioned goal (11 FUAs); the second most popular targets are related to the improvement and maintenance of infrastructure (10 FUAs).

The areas of interest were distinguished based on the information regarding tourism contained in the ITI Strategies of individual FUAs. All-year-round attractiveness of a region is a category that explains its purpose by its very name. It was especially concentrated around such regions as Lublin (not very popular destination for tourists, hence the creation of the John III Sobieski Route) or Szczecin (focus on water tourism, which is not available all year round). Bicycle routes have been singled out separately from the infrastructure itself due to the high frequency of replacement activities related to the construction of new bicycle paths or bicycle parking lots in many FUAs.

Business tourism was mentioned in the context of creating a favorable environment for local entrepreneurs and those travelling to a given FUA. Rzeszów was the only FUA to mention culinary aspects as an important area of interest. According to its strategy, it is important to promote the Podkarpackie Flavors Culinary Route. The municipalities that make up the Rzeszów FUA have proper resources and traditions in this area that allow them to develop this branch of tourism. Festivals and other cultural activities are closely linked to the previous category and relate to organized cultural events, such as St. Dominic's Fair in the GdańskGdynia-Sopot FUA or the Opera at the Castle organized in the Szczecin FUA.

Heritage and urban regeneration are one of the most common goals. It refers to the revitalization and development of existing buildings, which are considered monuments in the areas concerned. International communication appeared at the FUA of Gorzów Wielkopolski and referred to the possibility of cooperation with Germany to create cheap public transport between the two regions.

ICT applications and services related to culture and tourism which in the Szczecin FUA, for example, means the development of digital competences such as the creation of technical infrastructure of generally accessible wireless networks or, as in Warsaw, applications enabling foreign tourists to access the most important information about attractions or public transport. Infrastructure in FUAs in which they occurred meant primarily the renovation or construction of roads as well as railway and tram lines.

Natural resources are the most common area of interest among the FUAs and means e.g. the maintenance of bird protection areas and habitat protection areas (Wrocław FUA) or simply ensuring access to natural heritage by creating new tourist trails, tourist spots and advertising campaigns (Katowice FUA). Rural areas mean the development of rural areas and the use of the internal potential of all territories; the Rzeszów FUA stressed the role of high-quality rural space for living, working and recreation. Unique features of the city, such as textile industry or narrow-gauge trains in Lódź or health resorts in Lublin, are used for the creation of the regional tourist brand. 


\section{Discussion}

Modern tourists are not interested in a sole building or a heritage attraction; they rather evaluate the offer as a complex, considering as well accommodation, trip, overall experience and side services available [70]. All this creates closer links between branding and tourism activities. Content analysis conducted in the framework of the current study facilitated identification of the following aspects of tourism attractions and facilities that are within the focus of FUAs: all-year-round attractiveness of a region, bicycle routes, business tourism, culinary aspects, festivals and other cultural activities, heritage and urban regeneration, international communication, ICT applications and services related to culture and tourism, infrastructure, natural resources, rural areas, unique features of the city. Those findings go in line with the research of Zmyślony, who combined propositions of Page and Hall and Mika and distinguished the most common and parallel forms of tourism in the city (emphasizing that the list is not exhaustive): cultural and cognitive tourism, leisure tourism, visits by relatives and friends, individual business trips, conference and fair tourism, educational visits, religious tourism, sports tourism, entertainment tourism, event tourism (participation in events), shopping tourism (trade), health tourism, "urban leisure tourism" (including various forms of one-day activity by visitors) [71, p.61, 72, 73].

In order to explain the motivation of tourists to choose urban tourism, the " $4 \mathrm{~A}$ concept" is frequently recalled. The concept covers 'attractions', 'amenities', 'accommodation', 'access' [49, p. 125126]. In the extended $5 \mathrm{~A}$ version, 'atmosphere' was added [43]. Tourism-related goals identified within the current study represent four out of five groups according to the modified 5A strategy, combining both the categories suggested by Hughes and Kowalczyk: 'attractions', 'amenities', 'access', 'atmosphere'. It worth mentioning that the division between the categories is rather arbitrary because the achievement of each goal serves diverse purposes $[43,49]$.

The main attention of FUAs is placed on the attractions. 'Attraction' and 'attractiveness' describe the attributes of a city that make it interesting for tourists and force them to choose this destination [74]. Polish FUAs focus on attraction-related goals that can be shared into the following groups: a) business tourism, b) culture and traditions (culinary aspects, heritage and urban regeneration), c) nature tourism (natural resources, rural areas), d) unique features (creation of the tourist brand of the region). It shows the development of multidirectional tourism and the adaptation of tourism goals according to the demands and opportunities of a particular area.

The second biggest group is 'access' and it aims to improve communication accessibility of tourist reception areas [75]. It includes bicycle routes, infrastructure, international communication, which shows that FUAs consider both how the tourists will arrive at the travel destination and how they will travel around the location. Goals referred to 'amenities' include services for tourists [43]. The content analysis allowed to identify the following groups of services: all-year-round attractiveness of a region, ICT applications and services related to culture and tourism.

Goals referred to the 'atmosphere' category include festivals and other cultural activities. 'Atmosphere' as a goal is essential for the emotions and impressions received by tourists. Nevertheless, it is natural for emotion-related tasks to appear in branding strategies [76, 29]. In case of FUAs, a minor focus on the atmosphere can be explained by the fact that some areas are at an initial stage of implementing branding strategies, and brand-related emotions and associations have not been explicitly discussed yet. Thus, it can be observed that at the current stage the goals of FUAs are rather material-oriented.

The aspects of 'accommodation' is excluded from the strategies of development, which points out a certain gap in the tourism management approach used by Polish FUAs. The lack of the accommodation-related goals does not go in line with the majority of modern researches, because nowadays it is believed that the places to stay are of basic demand for tourist $[74,43]$. However, the above mentioned observation can be explained by the fact that the analyzed strategies focus on public objectives, while accommodation belongs to activities accomplished by the private sector.

In general, all the identified tourism attractions and facilities can be divided into material- and immaterial-oriented [38]. In most cases, FUAs are concentrated rather on material-oriented. The most common direction for FUAs is the maintenance and appropriate exploitation of natural resources. The second most common direction is the development of infrastructure. The third activity is related to heritage and urban regeneration. All of them belong to the group of material-oriented attractions and facilities. The dominance of material-oriented accomplishments can be explained by the emergency of city branding by Polish FUAs. Therefore, their current aim is to build a solid background for attracting tourists, and when the most essential issues are solved, there will be a space for the elaboration on the immaterial components of a city brand [51]. 


\section{ATMOSPHERE}

Festivals and Other Cultural Activities

\section{ATTRACTIONS}

Business Tourism Culinary Aspects Rural Areas

Unique features of the city

AMENITIES Natural Resources

Heritage and Urban Regeneration

ICT Applications and Services Related to Culture and Tourism All-Year Round Attractiveness of a Region

ACCESS

International Communication Bicycle Routes

Infrastructure

Immaterial Material

Where - - - - the borders of $4 A$ groups; the closer to the particular border - the more features of a given aspect this group has. The closer the group is located to the right-the more material it is; the more to the left-the more immaterial.

Fig. 2: Connections between material and immaterial city brand elements and elements of tourist attractiveness

Source: compiled by the authors.

The elements of the modified 5A model in tourism can be aligned with the material and immaterial elements of a brand infrastructure, which is visualized in the figure $2[49,43]$. Such elements as 'access' and 'amenities' are rather of a material nature; the 'atmosphere' is rather of an immaterial nature, and 'attractions' combine both material and immaterial aspects. However, the boundaries between the materiality of the majority of these categories is hard to define because the elements are of a complicated nature and all of them comprise both material and immaterial features $[77,78]$.

The current study allows to observe that tourism is an important component of the development of FUAs and it focuses both on the primary and secondary elements of the attractiveness of those areas. Primary elements are the main objectives for visiting a city [74] and for Polish FUAs they are the most widespread ones: business tourism, culinary aspects, festivals and other cultural activities, natural resources, rural areas, unique features of the city, heritage and urban regeneration. At the same time, secondary elements support the main attractions and contribute to the tourism development of a city are also of great importance: bicycle routes, international communication, ICT applications and services related to culture and tourism, infrastructure [74].

\section{Conclusions}

Modern cities grow and go beyond their formal borders, constructing new territorial units such as
FUAs. ITI Strategies are among key documents predetermining the directions of development of FUAs in Poland. They cover the most important aspects, including marketing, branding and tourism.

In the field of tourism in a FUA one can distinguish 12 types of attractions and facilities that can be shared into four (out of five) groups according to the modified 5A concept, combining the categories suggested by Hughes and Kowalczyk: 'attractions', 'amenities', 'access', 'atmosphere' [49, 43]. 'Accommodation' is excluded from the strategies of development which points out two main findings: FUAs focus rather on the 'material' component of their offer that can be explained by the fact that some FUAs are at the initial stage of development and implementation of branding strategies. Secondly, plans of FUAs do not cover the activities fulfilled by the private sector. In general, the research allows to notice that there is no common pattern for Polish FUAs regarding building a city tourist brand. Each area considers its resources, capabilities and target group expectations. However, a few most common trends can be distinguished: maintenance and appropriate exploitation of natural resources, improvement of infrastructure as well as development of heritage and urban regeneration facilities.

The conducted research, based on qualitative studies, provides solid ground for the proposal of a research hypothesis, the verification of which is planned in subsequent stages of the research:

Tourism as an important direction of branding activities of FUAs should take into account initiatives contributing to the shaping and promotion of an integrated tourism product, covering all communes that form a functional area, with particular emphasis on aspects related to building emotional associations with a city that translates into the FUA atmosphere.

Related to the hypothesis formulated above, among the directions of the consequent research can be mentioned deeper study of emotional associations with a city that translates into the FUA atmosphere and, therefore, influences the tourism attraction.

The significance of the study can be followed in the subsequent aspects. The first implication comes from the fact that city branding is becoming an increasingly popular governance practice. The results of these studies may be useful for municipalities to estimate what aspects of tourism as elements of a city brand are explicit enough in their strategies. From the perspective of academic literature, the paper contributes to the development of the city branding theory focusing on the issue of developing a tourist brand for FUAs. The results of the above studies may 
be useful for associations being units managing FUAs of the largest cities in Poland.

The key limitation of the paper is that it is focused on one type of documents, namely ITI Strategies of Polish FUAs only. That can be explained by the uniqueness of such bodies and by the preliminary nature of the conducted research. In the opinion of the authors, the results of research presented in this paper opens further research opportunities and within the following studies it is worth to conduct similar research in other countries. Another limitation is related to the specificity of the method, which is the analysis of document content. One should remember that documents are produced for a purpose other than the research goal; they are created independently of a research agenda [58]. These are the potential flaws rather than major disadvantages. Given its efficiency and cost-effectiveness in particular, document analysis offers advantages that clearly outweigh limitations [58].

\section{References:}

References:

[1] Alperyte I., Išo aite M., Developing a City Brand. Journal of Intercultural Management, vol.11, No.4, 2019, pp. 1-27.

[2] Braun E, City Marketing: Towards an Integrated Approach, Erasmus Research Institute of Management (ERIM), Rotterdam, 2008, https://repub.eur.nl/pub/13694/

[3] Ye L., Björner E. Linking city branding to multilevel urban governance in Chinese mega-cities: A case study of Guangzhou. Cities, vol.80, 2018, pp. 29-37.

[4] Boisen M., Terlouw K., Groote P., Couwenberg $\mathrm{O}$, Reframing place promotion, place marketing, and place branding - moving beyond conceptual confusion. Cities, vol.80, 2018, pp. 4-11.

[5] Papademetriou D.G., Sumption M., Attracting and selecting from the global talent pool - policy challenges. Migration Policy Institute, 2013, Available

at: https://www.migrationpolicy.org/research/attracti ng-and-selecting-global-talent-pool--policychallenges, accessed on 20.10.2018.

[6] Judd D.R., Promoting tourism in US cities, Tourism Management, Vol.16, No.3, 1995, pp. 175-187

[7] Markusen A., Schrock G., The distinctive city: Divergent patterns in growth, hierarchy and specialization, Urban Studies, Vol.43, No.8, 2006

[8] Hultman M., Yeboah-Banin A.A., Formaniuk L., Demand- and supply-side perspectives of city branding: A qualitative investigation, Journal of Business Research, 2016
[9] Klijn, E.H., Eshuis J., Braun E. The influence of stakeholder involvement on the effectiveness of place branding. Public Management Review, vol.14, No.4, 2012, pp. 499-519.

[10] Kociuba D., Miejskie Obszary Funkcjonalne wyzwania planistyczne, Vol.18, 2015, p. 45.

[11] ESPON 111 Potentials for polycentric development in Europe, Project report, 2004

[12] Kurek S., Wójtowicz M., Gałka J., Functional Urban Areas in Poland Demographic Trends and Migration Patterns, Springer Nature Switzerland AG, 2020, p. 1-3.

[13] Slach O., Bosák V., Krtička L., Nováček A., Rumpel P., Urban Shrinkage and Sustainability: Assessing the Nexus between Population Density, Urban Structures and Urban Sustainability, Sustainability, Vol.11, No.15, 2019, pp. 4142

[14] Central Statistical Office (2020). Retrieved from https://stat.gov.pl/

[15] Noworól A., Functional Urban Area as the city of the future. Czasopismo Techniczne, Architektura Zeszyt 1-A, 2014, pp. 149-150.

[16] Bartosiewicz, B., Obszary Funkcjonalne małych i średnich miast w Polsce - koncepcja badawcza. Zeszyty Naukowe Uniwersytetu Ekonomicznego w Katowicach, Vol.279, 2016, pp. 234-244.

[17] OECD www.oecd.org (accessed November 6, 2019).

[18] Busłowska A., Truskolaski T., Waligóra K., Formation of Functional Urban Areas: The Case of BIalystok Functional Area. Optimum. Studia Ekonomiczne, Vol.5, No.89, 2017

[19] Moreno-Monroy A. I., Schiavina M., Veneri P., Metropolitan areas in the world. Delineation and population trends. Journal of Urban Economics, 2020, Available at: https://doi.org/10.1016/j.jue.2020.103242

[20] Śleszyński P. Delimitacja Miejskich Obszarów Funkcjonalnych stolic województw. Przegląd Geograficzny, Vol.85, No.2, 2013, pp. 173-197.

[21] National Spatial Development Concept 2030, available at: https://www.kooperation-ohnegrenzen

[22] Szafranek D., Variability of the level of development of functional urban areas, Research Papers of Wroctaw University of Economics No.502, 2018, pp. 117-118.

[23] Matwiejczyk A., Glińska E., Barkun Y. Marketing and branding-oriented goals for the development of Functional Urban Areas: evidence from Poland. Engineering Management in Production and Services, Vol.12, No.3, 2020

[24] Yunfeng H., Yueqi H., Identification of Urban Functional Areas Based on POI Data: A Case Study of the Guangzhou Economic and 
Technological Development Zone, Sustainability, Vol.11, No.5, 2019, 1385.

[25] Paradowska M., Platje J., European sustainable urban development policy in the light of priorities of the Europe 2020 Strategy. Journal of Economics and Management, Vol.19, No.1, 2015, pp. $95-107$.

[26] Glińska E., Rudolf, W., City Brand Personality Projected by Municipalities from Central and Eastern Europe Countries - A Comparison of Facebook Usage. Sustainability, Vol.11, No.19, 2019,5440

[27] Maheshwari V., Lodorfos G., Dennis J., Vandewalle I., Branding a place: a growth and development perspective, 2012. Available at: $\mathrm{http} / / /$ marketing.conference-services.net/ resources/327/2958/pdf/AM2012_0257_paper.pd $\mathrm{f}$

[28] Kavaratzis M., From city marketing to city branding: Toward a theoretical framework for developing city brands, Place Branding, Vol.1, No 1, 2004, pp. 58-73

[29] Florek M. Kapitat marki miasta zorientowany na konsumenta. Źródta $i$ pomiar, Wydawnictwo Uniwersytetu Ekonomicznego w Poznaniu, Poznań, 2014

[30] Hankinson G., Rethinking the Place Branding Construct (in:) Rethinking Place Branding. Comprehensive Brand Development for Cities and Regions, ed. M. Kavaratzis, G. Warnaby, G. Ashworth, Springer, London, 2015

[31] Kavaratzis M., Hatch M.J. The Dynamics of Place Branding: An Identity-based Approach to Place Branding Theory. Marketing Theory, Vol. 13, No.1, 2013, pp. 69-86

[32] Zhang L., Zhao S.X., City branding and the Olympic effect: A case study of Beijing. Cities, Vol.26, No.5, 2009, pp. 245-254.

[33] Fan, Y., Branding the nation: What is being branded? Journal of Vacation Marketing, Vol.12, 2006, pp. 5-14.

[34] Gilboa S., Jaffe E.D., Vianelli D., Pastore A., Herstein R., A summated rating scale for measuring city image. Cities, Vol.44, 2015, pp. $50-59$.

[35] Merrilees B., Miller D., Herington C., City branding: A facilitating framework for stressed satellite cities. Journal of Business Research, Vol.66, No.1, 2013, pp. 37-44.

[36] Middleton A.C., City Branding and Inward Investments (In:) City Branding: Theory and Cases, ed. K. Dinnie, Palgrave Macmillan, Basingstoke, 2011

[37] Prayag G., Brand image assessment: international visitors' perceptions of Cape Town.
Marketing Intelligence \& Planning, Vol.28, pp. 2011, pp. 462-485.

[38] Glińska E., Kobylińska U. (ed.) Identyfikacja cech wyróżniajacych tożsamość miasta $w$ procesie zarzadzania jego marka. Perspektywa lokalnych interesariuszy, Oficyna Wydawnicza Politechniki Białostockiej, Białystok, 2014

[39] Hanna S., Rowley J., Towards a strategic place brand-management model. Journal of Marketing Management, Vol.27, No.5-6, 2011, pp. 458476.

[40] Zenker S., Jacobsen B. Inter-regional place branding: Best practices, challenges and solutions, 2015 Available at: https://www.google.com/books?hl=sv\&lr=\& id=bIz1BwAAQBAJ\&oi=fnd\&pg=PR5\&dq=Int er-Regional+Place+Branding\& ots $=20 \mathrm{GvQSwe} 25 \& \mathrm{sig}=\mathrm{FGbOO} 03 \mathrm{oXq} 2 \mathrm{rto} 7 \mathrm{aGf}$ byNV89tiQ, accessed 20.04.2020

[41] Gilboa S., Herstein R., Place status, place loyalty and well being: an exploratory investigation of Israeli residents. Journal of Place Management and Development, Vol.5, No.2, 2012, pp. 141157.

[42] Glińska, E., Powichrowska B., SidorczukPietraszko E., Możliwości i bariery budowania marki miejskiego obszaru funkcjonalnego studium przypadku. Przedsiębiorczość $i$ zarzadzanie, Vol.XVII, No.4/III, 2016, pp. 45-58.

[43] Kowalczyk A., Nowe formy turystyki miejskiej, Prace i Studia Geograficzne, vol.35, 2005, pp. 155-197.

[44] Pasquinelli, C., Competition, cooperation and co-opetition: unfolding the process of Development of a brand idea as the basis interterritorial branding, Urban Research and Practice, Vol.6, No.1, 2013, pp. 1-18.

[45] Ashworth G. Do we understand urban tourism? Tourism \& Hospitality, Vol.1, No.4, 2012, pp. 12

[46] Lerario A., S. Di Turi, Sustainable Urban Tourism: Reflections on the Need for BuildingRelated Indicators. Sustainability, Vol.10, No.6, 2018, 1981.

[47] Ashworth G., Page S., Urban tourism research: Recent progress and current paradoxes, Tourism Management, Vol.32, No.1, 2011, pp. 1-15.

[48] Edwards D., Griffin T., Hayllar B., Urban Tourism Research Developing An Agenda, Annals of Tourism Research, Vol.35, No.4, 2008, pp. 1032-1052.

[49] Hughes H., Arts, Entertainment and Tourism, Butterworth-Heinemann, Oxford-Burlington, 2003, pp. 125-126. 
[50] De Noni, I., Orsi, L., Zanderighi, L., Stereotypical versus experiential destination branding: The case of Milan city. City, Culture and Society, Vol.17, 2019, pp. 38-45

[51] Herget, J., Petrů, Z., Abrhám, J., City branding and its economic impacts on tourism, Economics and Sociology, Vol.8, No.1, 2015, pp. 119-126.

[52] De Carlo, M., Canali, S., Pritchard, A., Morgan, N. Moving Milan towards Expo 2015: Designing culture into a city brand. Journal of Place Management and Development, Vol.2, No.1, 2009, pp. 8-22.

[53] Rabbiosi C., Place branding performances in tourist local food shops. Annals of Tourism Research, Vol.60, 2016, pp. 154-168.

[54] Beerli, A., Martin, J.D., Factors influencing destination image. Annals of Tourism Research, Vol.31, No.3, 2004, pp. 657-681.

[55] Popescu R.I., Corboş R.A., The role of urban tourism in the strategical development of Brasov area. Theoretical and Empirical Researches in Urban Management, Vol.7, No.16, 2010, p. 71.

[56] Law C.M., Urban Tourism The Visitor Economy and the Growth of Large Cities, 2001, p. 41.

[57] Szpilko D., The use of Delphi method in the process of building a tourism development strategy in the region. Engineering Management in Production and Services, Vol.6, No.4, 2014, p. 330

[58] Bowen G. A., Document Analysis as a Qualitative Research Method, Qualitative Research Journal, Vol.9, No.2, 2009, pp. 27-40.

[59] Alsalloum A., Brown A., Towards a HeritageLed Sustainable Post-Conflict Reconciliation: A Policy-Led Perspective, Sustainability, Vol.11, No.6, 2019, 1686.

[60] Huang X., Zhao D., Brown C. G., Wu Y., Waldron S.A., Environmental Issues and Policy Priorities in China: A Content Analysis of Government Documents, China: An International Journal, Vol.8, No.2, 2010, pp. 220-246.

[61] Masik G., SaganI., Scott j. W., Smart City strategies and new urban development policies in the Polish Context, Cities, vol. 108, 2021, 102970

[62] Marketingowa Strategia Polski w sektorze turystyki na lata 2012-2020, https://www.pot.gov.pl/pl/o-pot/plany-isprawozdania-pot/marketingowa-strategiapolski-w-sektorze-turystyki-na-lata-2012-20202.

[63] Regulation (EU) No 1301/2013 of the European Parliament and of the Council of 17 December 2013 (accessed April 18, 2020).
[64] Regulation (EU) No 1303/2013 of the European Parliament and of the Council of 17 December 2013 (accessed April 18, 2020).

[65] Regulation (EU) No 1304/2013 of the European Parliament and of the Council of 17 December 2013 (accessed April 18, 2020).

[66] Article 74 of the Act of 8 March 1990 on Municipal Self-Government (accessed April 18, 2020).

[67] Flick, U., Projektowanie Badania Jakościowego, Wydawnictwo Naukowe PWN, Warsaw, Poland, 2012

[68] Labuschagne A., Qualitative research: Airy fairy or fundamental? The Qualitative Report, Vol.8, No.1, Art.7, 2003, Access: https://pdfs.semanticscholar.org/4500/99050d7c4 0013ec150fa5907b1023a14b45c.pdf?_ga $=2.266$ $849870.1108621567 .1587215027-$ 396449049.1585317866

[69] Hsieh H.; Shannon S.E., Three approaches to qualitative content analysis, Qualitative Health Research, Vol.15, 2005, pp. 1277-88.

[70] Vinyals-Mirabent S. European urban destinations' attractors at the frontier between competitiveness and a unique destination image. A benchmark study of communication practices. Journal of Destination Marketing \& Management, Vol.12, 2019, pp. 37-45.

[71] Zmyślony P, Funkcja turystyczna w procesie internacjonalizacji miast, Kraków: Proksenia, 2015

[72] Page S.J., Hall C.M. Managing urban tourism, Prentice Hall, Harlow, 2003

[73] Mika M., Miasta jako obszary recepcji turystycznej, [in:] Kraków jako ośrodek turystyczny, M. Mika (ed.), Instytut Geografii i Gospodarki Przestrzennej Uniwersytetu Jagielońskiego, Kraków, 2011, pp. 15-33

[74] Boivin M., Tanguay G.A., Analysis of the determinants of urban tourism attractiveness: The case of Québec City and Bordeaux. Journal of Destination Marketing \& Management, Vol.11, 2019, pp. 67-79.

[75] Lapko A., Urban Tourism in Szczecin and its Impact on the Functioning of the Urban Transport System. Procedia - Social and Behavioral Sciences, Vol.151, 2014, pp. 207-214.

[76] Daszkiewicz M., Wołosecka A. Development of a brand idea as the basis for region branding. A case study of the Jizera mountains and the foreland region. Scientific Papers of Silesian University of Technology. Organization and Management, vol.139, 2019, pp. 107-121.

[77] de Chernatony L., McWilliam G., Appreciating brands as assets through using a two-dimensional 
model. Journal of Marketing Management, vol.9, No.1, 1990, pp. 173-188

[78] Giovanardi M., Haft and sord factors in place branding: Between functionalism and representationalism, Place Branding and Public Diplomacy, Vol.8, No.1, 2012, pp. 30-45.

Contribution of individual authors to the creation of a scientific article (ghostwriting policy)

Ewa Glińska, Anna Matwiejczyk, Yauheniya Barkun - Conceptualization, writing and editing.

Yauheniya Barkun was responsible for figures.

Percentage contributions are EG: 33,3\%, YB: $33,3 \%$, AM: $33,3 \%$. All authors read and approved the final manuscript.

\section{Sources of funding for research presented in a scientific article or scientific article itself}

This study was funded by Bialystok University of Technology (WZ/WIZ-INZ/2/2020, WI/WIZINZ/3/2020, WI/WIZ-INZ/6/2020)

\section{Creative Commons Attribution}

\section{License 4.0 (Attribution 4.0 \\ International, CC BY 4.0)}

This article is published under the terms of the Creative Commons Attribution License 4.0

https://creativecommons.org/licenses/by/4.0/deed.en US 